\title{
Magnetic Properties, Microstructure and Corrosion Resistance of Ce-doped $\mathrm{Sm}_{1-\mathrm{x}} \mathrm{Ce}_{\mathrm{x}}\left(\mathrm{Co}_{\text {bal }} \mathrm{Fe}_{0.14} \mathrm{Cu}_{0.07} \mathrm{Zr}_{0.05}\right)_{7.5}$ Magnets
}

\author{
Changquan Zhou ${ }^{1}$, Yong $\mathrm{Gu}^{2, *}$, Minxiang Pan $^{3}$ \\ ${ }^{1}$ Zhejiang University of Water Resources and Electric Power, Hangzhou 310018, P. R. China \\ ${ }^{2}$ Qianjiang College, Hangzhou Normal University, Hangzhou 310036, P. R. China \\ ${ }^{3}$ China Jiliang University, Hangzhou 310018, P. R. China \\ *E-mail: guyonghz@126.com
}

doi: $10.20964 / 2020.02 .33$

Received: 21 October 2019 / Accepted: 28 November 2019 / Published: 31 December 2019

The influence of the Ce content and the relation among the magnetic properties, corrosion resistance and microstructure of the $\mathrm{Sm}_{1-\mathrm{x}} \mathrm{Ce}_{\mathrm{x}}\left(\mathrm{Cobal}_{\mathrm{be}} \mathrm{Fe}_{0.14} \mathrm{Cu}_{0.07} \mathrm{Zr}_{0.05}\right)_{7.5}$ magnets are systemically studied. The enhanced magnetic properties $\left(B_{\mathrm{r}}=11.01 \mathrm{kG}, H_{\mathrm{cj}}=15.5 \mathrm{kOe}\right.$, and $\left.(B H)_{\max }=30.1 \mathrm{MGOe}\right)$ have been obtained with the slight $\mathrm{Ce}$-doped $(\mathrm{x}=0.1)$. The lower values of the corrosion potential $E_{\text {corr }}$ and corrosion current density $i_{\text {corr }}$ for the Ce-doped magnet indicate that electrochemical corrosion rate of the Ce-doped magnet slows down and the corrosion resistance of the magnet is stronger. The microstructure results show that the Ce-doped magnet obtains a more uniform cellular structure with the smaller cell size and the homogeneous cell boundary phase, while the content of the Ce shows no observable difference between the cell and cell boundary.

Keywords: Corrosion; SmCo; Ce; Magnetic properties; Cell size

\section{FULL TEXT}

(C) 2020 The Authors. Published by ESG (www.electrochemsci.org). This article is an open access article distributed under the terms and conditions of the Creative Commons Attribution license (http://creativecommons.org/licenses/by/4.0/). 